Jurnal Agratech 10 (1) 27-34, Juni 2020

e-ISSN : 2621-7236

p-ISSN : 1858-134X

\title{
PENGARUH Trichoderma asperellum DAN KOMPOS TERHADAP PERTUMBUHAN DAN HASIL TANAMAN BAWANG MERAH VARIETAS LEMBAH PALU (Allium L.x Wakegi Araki)
}

\author{
EFFECT OF Trichoderma asperellum AND COMPOSITE ON GROWTH \\ AND RESULTS OF SHALLOT VARIETY OF PALU VALLEY \\ (Allium L.x Wakegi Araki)
}

\author{
Kasman Jaya $^{1}$, Idris ${ }^{1 *}$ dan Yuliana ${ }^{1}$ \\ ${ }^{1}$ Program Studi Agroteknologi Fakultas Pertanian Universitas Alkhairaat, Jl. Diponegoro, Fakultas \\ Pertanian Universitas Alkhairaat, Palu 94221, Indonesia
}

\begin{abstract}
ABSTRAK
Penelitian ini bertujuan untuk mengetahui pengaruh pemberian T. asperellum dan kompos terhadap pertumbuhan dan hasil tanaman bawang merah varietas Lembah Palu. Penelitian ini dilaksanakan pada bulan Juli sampai September 2019 di Desa Oloboju Kecamatan Sigi Biromaru Kabupaten Sigi, Provinsi Sulawesi Tengah. Penelitian ini termasuk jenis penelitian experiment yang didesain menggunakan Rancangan Acak Kelompok (RAK) dengan pengelompokan berdasarkan waktu penyiraman. Perlakuan yang dicobakan terdiri dari: $\mathrm{P}_{0}=$ Kontrol (tanpa perlakuan), $\mathrm{P}_{1}=T$. asperellum $48 \mathrm{~g}+12$ liter air, $\mathrm{P}_{2}=T$. asperellum $48 \mathrm{~g}+$ kompos $12 \mathrm{~kg}$ dan $\mathrm{P}_{3}=$ Kompos $12 \mathrm{~kg}$. Untuk mengetahui pengaruh perlakuan yang dicobakan, maka dilakukan uji keragaman. Bila hasil uji keragaman menunjukkan pengaruh nyata, maka dilanjutkan dengan uji Beda Nyata Jujur (BNJ) $\alpha=0,05$ untuk mengetahui perbedaan antar perlakuan. Perlakuan berbagai kombinasi $T$. asperellum dan kompos berpengaruh nyata terhadap tinggi tanaman umur 15 dan 25 HST, tetapi berpengaruh tidak nyata terhadap jumlah daun, berat segar daun, berat segar akar, berat kering daun, berat kering akar, jumlah umbi per rumpun, berat segar umbi per rumpun, berat segar umbi per petak dan berat segar umbi per hektar. Perlakuan kompos memberikan pengaruh lebih baik terhadap tinggi tanaman umur 15 HST (rata-rata 15,09cm) dan 25 HST (rata-rata 19,86cm).
\end{abstract}

Katakunci : T. asperellum, Kompos, Bawang Merah

\section{ABSTRACT}

This study aims to determine the effect of giving T. asperellum and compost on the growth and yield of shallots of the Palu Valley variety. This research was conducted on July to September 2019 in Oloboju Village, Sigi Biromaru District, Sigi Regency, Central Sulawesi Province. This research is a kind of experimental research that is designed by using a Randomized Group Design with grouping based on watering time. The treatments tested consisted of: $P 0=$ Control (without treatment), $P 1=T$. asperellum $48 \mathrm{~g}+12$ liters of water, $P 2=T$. asperellum $48 \mathrm{~g}+12 \mathrm{~kg}$ compost and $P 3=12 \mathrm{~kg}$ compost. To determine the effect of the treatment being tried, a diversity test was conducted. If the diversity test results show a real influence, then proceed with the Honestly Significant Difference test (BNJ) $\alpha=0.05$ to find out the differences between treatments. Treatment of various combinations of $T$. asperellum and compost significantly affected plant height at ages 15 and 25 HST, but had no significant effect on the number of leaves, leaf fresh weight, root fresh weight, leaf dry weight, root dry weight, number of tubers per clump, fresh tuber weight per clump, fresh tuber weight per plot and fresh tuber weight per hectare. The compost treatment gives a better effect on the height of plants aged $15 \mathrm{HST}$ (average $15.09 \mathrm{~cm}$ ) and $25 \mathrm{HST}$ (average $19.86 \mathrm{~cm}$ ).

Keywords: T. asperellum, Compost, Shallots

\section{Pendahuluan}

Bawang merah merupakan salah satu

\footnotetext{
${ }^{*}$ Penulis Korespondensi.

E-mail: idris.doank45@gmail.com

Telp: +62-85241160584
}

komoditas hortikultura yang mendapat prioritas pengembangan, karena potensi pasarnya yang baik dan sumber daya alam yang mendukung. Salah satu jenis bawang merah yang dikembangkan oleh masyarakat di Sulawesi Tengah adalah Bawang merah varietas Lembah Palu (Allium L.x Wakegi Araki). Bawang merah 
ini memiliki arti penting karena dibutuhkan sebagai bahan baku untuk menghasilkan bawang goreng kualitas baik.

Tanaman bawang merah dapat ditanam dan tumbuh di dataran rendah sampai ketinggian $1.000 \mathrm{~m}$ dpl. Walaupun demikian, untuk pertumbuhan optimal adalah pada ketinggian 0 $450 \mathrm{~m}$ dpl. Komoditas sayuran ini umumnya peka terhadap keadaan iklim yang buruk seperti curah hujan yang tinggi serta keadaan cuaca yang berkabut. Tanaman bawang merah membutuhkan penyinaran cahaya matahati yang maksimal (minimal $70 \%$ penyinaran), suhu udara $25^{\circ}-32^{\circ}$ $\mathrm{C}$ serta kelembaban nisbi yang rendah (Sutaya $d k k ., 1995)$. Tanaman bawang merah sangat peka terhadap curah hujan dan kelembaban yang tinggi. Kondisi iklim yang lembab mendukung perkembangan penyakit bawang merah terutama dari golongan cendawan.

Minat petani terhadap bawang merah cukup besar, namun dalam proses budidayanya masih ditemui berbagai kendala, baik yang bersifat teknis maupun ekonomis. Salah satu kendala teknis yang sering ditemui di lahan adalah gangguan penyakit pada bawang merah. Salah satunya yaitu bercak ungu dan moler.

Cendawan antagonis Trichoderma sp. mempunyai kemampuan sebagai parasit dan bersifat antibiosis karena menghasilkan enzim yang secara aktif mampu mendegradasi sel-sel patogen, sehingga menyebabkan lisisnya sel-sel cendawan patogen dan mengeluarkan trikotoksin yang mematikan cendawan patogen (Liswarni $d k k .$, 2007).

Salah satu kendala dalam pemanfaatan Trichoderma sebagai agens pengendali hayati yaitu rendahnya kemampuan adaptasi dan pekembangan populasi Trichoderma setelah diintroduksikan ke dalam tanah. Menurut Nurbailis \& Martinius (2011) agens hayati sebelum diintroduksikan ke dalam tanah sebaiknya diperbanyak secara massal pada bahan organik yang sesuai untuk pertumbuhan dan perkembangan agar dapat beradaptasi pada lingkungan yang baru setelah diintroduksikan ke dalam tanah. Kemampuan beradaptasi dan perkembangan Trichoderma pada ekosistem pertanaman sangat menentukan dalam keberhasilan tanaman yang berkelanjutan.

Pupuk kimia sintesis mengandung bahan kimia yang dapat menurunkan mikroba dalam tanah dan merusak struktur tanah. Alternatif mengatasi permasalahan tersebut adalah menggunakan pupuk organik. Penggunaan pupuk
p-ISSN : 1858-134X

organik salah satunya menggunakan kompos. Masalah yang sering ditemui ketika menerapkan pertanian organik adalah adanya patogen dalam tanah. Perlu adanya penambahan mikroba tanah untuk mengurangi patogen dalam tanah. Penambahan mikroba tanah juga dapat mempercepat proses pendegradasian pupuk kompos (Isroi, 2004). Mikroba yang digunakan adalah T. asperellum isolat Ratnawati, 2019.

Kompos merupakan hasil penguraian dari campuran bahan-bahan organik yang dapat dipercepat oleh populasi berbagai macam mikroorganisme dalam kondisi lingkungan yang hangat, lembab, dan aerobik atau anaerobik. Manfaat kompos Kompos ibarat multivitamin bagi tanah dan tanaman. Sutanto (2002) mengemukakan bahwa dengan pupuk organik sifat fisik, kimia dan biologi tanah menjadi lebih baik.

Trichoderma sp lebih efektif dan ramah lingkungan untuk mengurangi presentase dan intensitas penyakit pada tanaman bawang merah. Menurut Ratnawati (2019), hasil uji isolat cendawan Trichoderma asal filosfer mampu menutupi secara keseluruhan kolonji cendawan patogen dimana kisaran presentae penghambatan antara $43,30 \%-82,05 \%$.

\section{Metode Penelitian}

Penelitian ini termasuk jenis penelitian experiment yang didesain menggunakan Rancangan Acak Kelompok (RAK) dengan pengelompokan berdasarkan waktu penyiraman. Terdapat 4 perlakuan dan masing-masing perlakukan diulang sebanyak $4 \mathrm{kali}$, sehingga terdapat 16 unit perlakuan. Perlakuan tersebut terdiri dari :

$\mathrm{P}_{0}$ :Kontrol (tanpa T. asperellum, tanpa kompos)

$\mathrm{P}_{1}:$ T. asperellum FLS $48 \mathrm{~g}+12$ liter air

$\mathrm{P}_{2}:$ T asperellum FLS $48 \mathrm{~g}+$ kompos $12 \mathrm{~kg}$

$\mathrm{P}_{3}:$ Kompos $12 \mathrm{~kg}$

\section{Pelaksanaan}

Pembuatan kompos

Pembuatan kompos terdiri dari gulma alangalang, daun gamal dan gulma siam yang diperoleh dari bahan yang spesifik lokasi. Masing-masing bahan digunakan dengan perbandingan 1:1:1. Gulma alang-alang, daun gamal dan gulma siam diambil dari lahan kemudian dicacah menggunakan chopper sehingga volumenya sedikit lebih halus, setelah itu ketiga bahan tersebut dicampur lalu dimasukkan dalam karung beras dan diikat serta 
diberi lubang untuk sirkulasi udara. Fermentasi ini dilakukan selama 1 bulan. Untuk dosis kompos digunakan 10 ton / ha.

Persiapan lahan

Persiapan lahan diawali dengan pengukuran lahan kemudian dilanjutkan pengolahan lahan pertama, yakni membajak tanah menggunakan hand traktor. Pengolahan tanah kedua dilakukan lima hari setelah pengolahan tanah pertama, lalu dilanjutkan dengan pembuatan bedengan tiga hari setelah pengolahan tanah kedua. Bedengan berukuran panjang $10 \mathrm{~m}$, lebar $1,2 \mathrm{~m}$ dan tinggi $\pm 25 \mathrm{~cm}$ sebanyak 16 petak.

Aplikasi perlakuan

Aplikasi T. asperellum dan kompos dilakukan tiga hari sebelum penanaman.

1. Dosis T. asperellum yang digunakan sesuai dengan perlakuan yang dicobakan, yakni 48 g $T$. asperellum yang dicampur dengan air sebanyak 12 L kemudian disemprotkan pada seluruh permukaan petak percobaan menggunakan sprayer secara merata.

2. T. asperellum $48 \mathrm{~g}+$ kompos $12 \mathrm{~kg}$ dicampur dengan cara melarutkan $T$. asperellum dengan air secukupnya kemudian disebar secara merata ke kompos, campuran $T$. asperellum dan kompos disebar secara merata pada seluruh permukaan petak percobaan dan dibolak-balik hingga tercampur dengan tanah di petak percobaan.

3. Kompos $12 \mathrm{~kg}$ disebar secara merata pada seluruh permukaan petak percobaan, selanjutnya dibolak-balik hingga tercampur dengan tanah di petak percobaan.

Penanaman

Penanaman bawang merah lembah palu dilakukan dengan jarak tanam $20 \times 15 \mathrm{~cm}$. Benih bawang merah lembah palu yang digunakan adalah benih bawang yang telah disimpan selama 2 bulan setelah panen. Benih bawang merah ditanam dengan cara ditugal sedalam $\pm 2 \mathrm{~cm}$. Setiap lubang ditanami dengan 1 benih.

Pemeliharaan

Pemeliharaan tanaman meliputi penyulaman, penyiraman, pemasangan mulsa alang-alang, penyiangan, pengendalian hama. Penyulaman dilakukan untuk mengganti benih yang tumbuh tidak normal atau mati. Penyiraman diberikan setiap 3 hari sekali atau berdasarkan kondisi media tumbuh. Penyiraman dilakukan menggunakan sprinkle. Penyiraman pada saat pagi hari dimulai kelompok 1 pukul 07.00 07.30, kelompok 2 pukul 07.40 - 08.10, kelompok 3 pukul $08.20-08.50$ dan kelompok 4
09.00 - 09.30. Mulsa alang-alang diberi sehari setelah tanam. Penyiangan dilakukan seminggu sekali, dengan cara mencabut gulma. Pengendalian hama dilakukan dengan cara memasang likat kuning dan lampu perangkap. Pemasangan likat kuning dimulai 2 HST, diganti setiap 7 hari sekali. Lampu perangkap dinyalakan mulai pukul 18.00-06.00.

Panen

Bawang merah varietas Lembah Palu dipanen setelah berumur 65 HST. Panen dilakukan dengan cara mencabut seluruh tanaman secara hati-hati.

\section{Hasil dan Pembahasan}

\section{Hasil}

Jumlah daun (helai)

Hasil sidik ragam menunjukkan bahwa perlakuan T. asperellum dan kompos terhadap jumlah daun pada umur 15, 25 dan 35 memberikan pengaruh tidak nyata. Seperti disajikan pada Gambar 1.

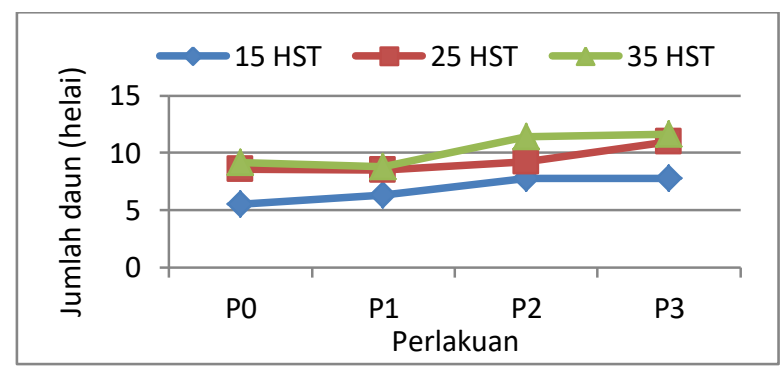

Gambar 1. Rata-rata jumlah daun umur 15, 25 dan 35 HST.

Tinggi tanaman $(\mathrm{cm})$

Hasil sidik ragam menunjukkan bahwa perlakuan $T$. asperellum dan kompos terhadap tinggi tanaman berpengaruh sangat nyata pada umur $15 \mathrm{HST}$, berpengaruh nyata pada umur 25 HST dan berpengaruh tidak nyata pada umur 35 HST.

Hasil uji BNJ $\alpha \quad 0.05 \quad($ Tabel 1) menunjukkan bahwa perlakuan kompos memberikan pengaruh yang lebih baik pada pertumbuhan tinggi tanaman bawang merah varietas lembah palu, meskipun berbeda tidak nyata dengan perlakuan lainnya kecuali kontrol yang menghasilkan tinggi tanaman paling rendah. 
Jurnal Agratech 10 (1) 27-34, Juni 2020

Tabel 1. Rata-rata tinggi daun $(\mathrm{cm})$ tanaman bawang merah varietas Lembah Palu umur 15, 25 dan 35 HST

\begin{tabular}{cccc}
\hline \multirow{2}{*}{ Perlakuan } & \multicolumn{3}{c}{ Rerata } \\
\cline { 2 - 4 } & $\begin{array}{c}\text { Umur 15 } \\
\text { HST }\end{array}$ & $\begin{array}{c}\text { Umur 25 } \\
\text { HST }\end{array}$ & $\begin{array}{c}\text { Umur 35 } \\
\text { HST }\end{array}$ \\
\hline $\mathrm{P}_{0}$ & $9.08 \mathrm{~b}$ & $15.08 \mathrm{~b}$ & 18.54 \\
$\mathrm{P}_{1}$ & $13.77 \mathrm{a}$ & $19.19 \mathrm{a}$ & 19.28 \\
$\mathrm{P}_{2}$ & $14.25 \mathrm{a}$ & $19.55 \mathrm{a}$ & 20.53 \\
$\mathrm{P}_{3}$ & $15.09 \mathrm{a}$ & $19.86 \mathrm{a}$ & 20.70 \\
\hline
\end{tabular}

\begin{tabular}{cccc} 
BNJ 5\% & 1.38 & 2.27 & - \\
\hline Keterangan : Angka yang diikuti oleh huruf yang
\end{tabular} sama pada kolom yang sama berarti berbeda tidak nyata pada taraf uji BNJ $\alpha$ $=0,05$

Berat segar daun (g)

Hasil sidik ragam menunjukkan bahwa perlakuan $T$. asperellum dan kompos terhadap berat segar daun pada umur 40 HST berpengaruh tidak nyata. Seperti disajikan pada Gambar 2.

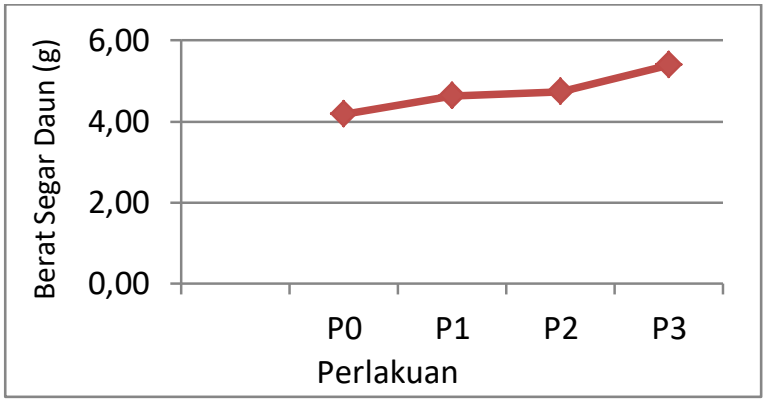

Gambar 2. Rata-rata berat segar daun umur 40 HST

Berat segar akar $(\mathrm{g})$

Hasil sidik ragam menunjukkan bahwa perlakuan T. asperellum dan kompos terhadap berat segar akar pada umur 40 HST berpengaruh tidak nyata. Seperti disajikan pada Gambar 3.

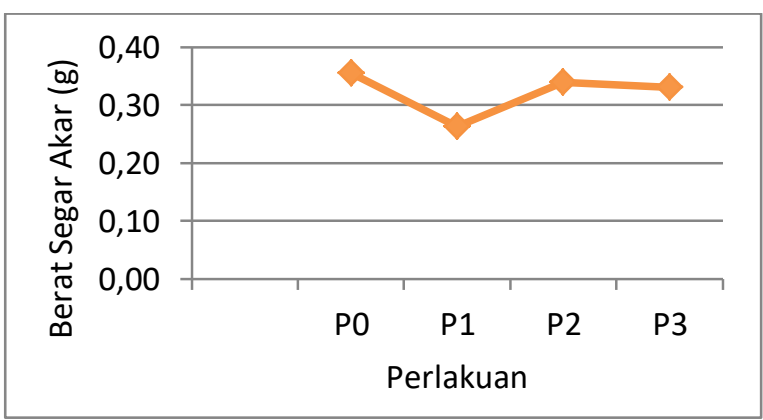

Gambar 3. Rata-rata berat segar akar umur 40 HST

Berat kering daun (gr)

Hasil sidik ragam menunjukkan bahwa perlakuan $T$. asperellum dan kompos terhadap berat kering daun pada umur 40 HST berpengaruh tidak nyata.
e-ISSN : 2621-7236

p-ISSN : 1858-134X

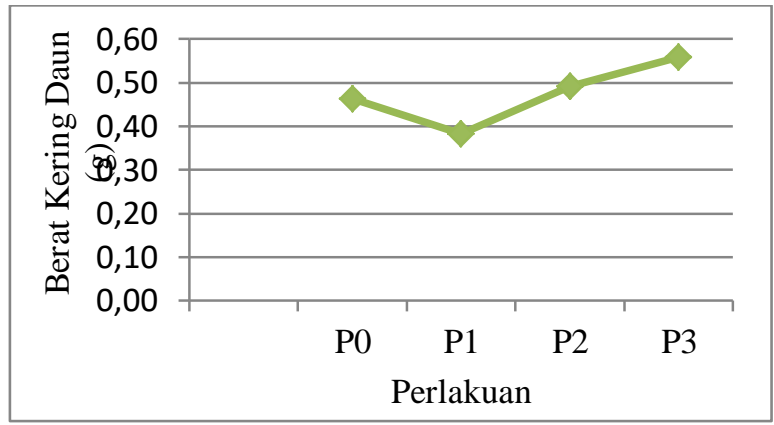

Gambar 4. Rata-rata berat kering daun umur 40 HST

Berat kering akar (g)

Hasil sidik ragam menunjukkan bahwa perlakuan $T$. asperellum dan kompos terhadap berat kering akar pada umur 40 HST berpengaruh tidak nyata.

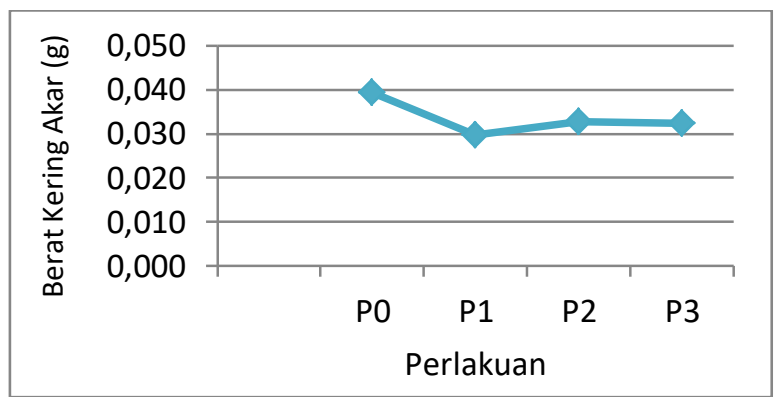

Gambar 5. Rata-rata berat kering akar umur 40 HST

Jumlah umbi per rumpun (buah)

Hasil sidik ragam menunjukkan bahwa perlakuan $T$. asperellum dan kompos terhadap jumlah umbi per rumpun saat panen berpengaruh tidak nyata.

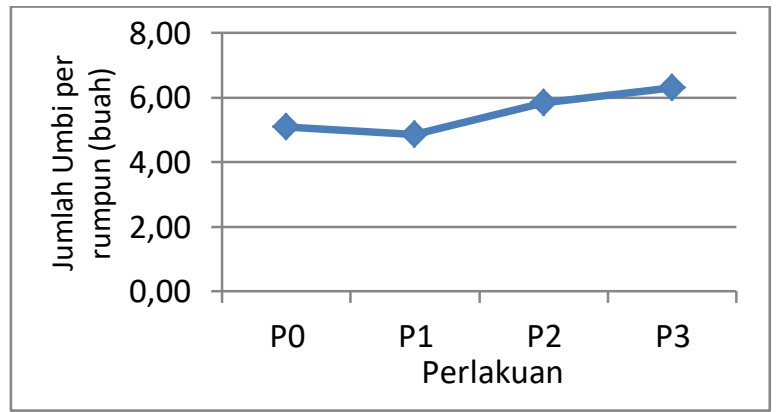

Gambar 6. Rata-rata jumlah umbi tanaman bawang merah saat panen

Berat segar umbi per rumpun $(\mathrm{g})$

Hasil sidik ragam menunjukkan bahwa perlakuan $T$. asperellum dan kompos terhadap berat segar umbi per rumpun saat panen berpengaruh tidak nyata. 
Jurnal Agratech 10 (1) 27-34, Juni 2020

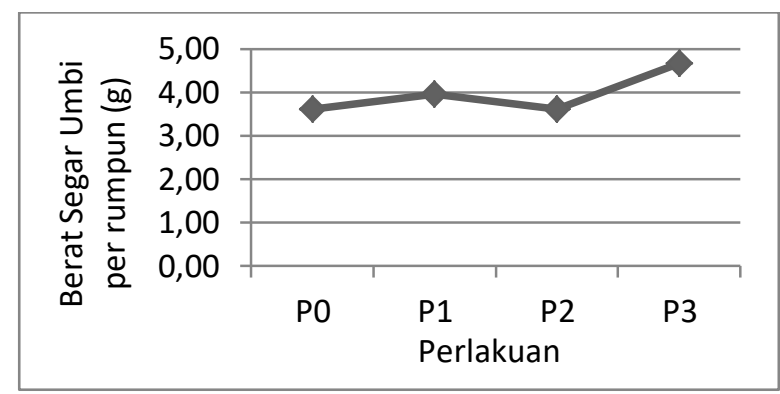

Gambar 7. Rata-rata berat segar umbi per rumpun tanaman bawang merah saat panen

Berat segar umbi per petak $(\mathrm{kg})$

Hasil sidik ragam menunjukkan bahwa perlakuan T. asperellum dan kompos terhadap berat segar umbi per petak saat panen berpengaruh tidak nyata.

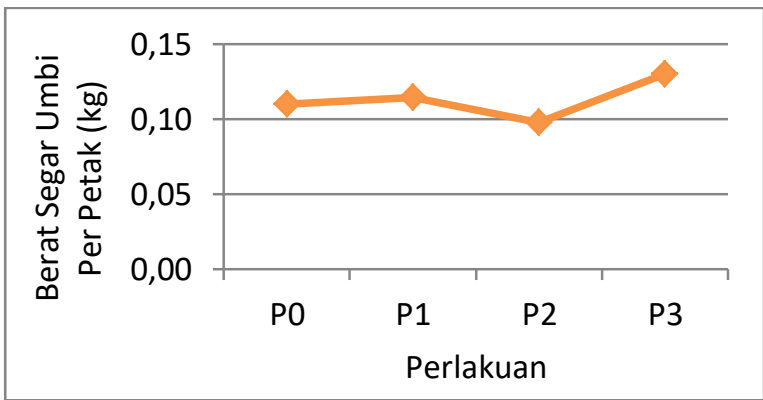

Gambar 8. Rata-rata berat segar umbi per petak tanaman bawang merah saat panen

Berat segar umbi per hektar ( $\mathrm{t}$ )

Hasil sidik ragam menunjukkan bahwa perlakuan $T$. asperellum dan kompos terhadap berat segar umbi per hektar saat panen berpengaruh tidak nyata.

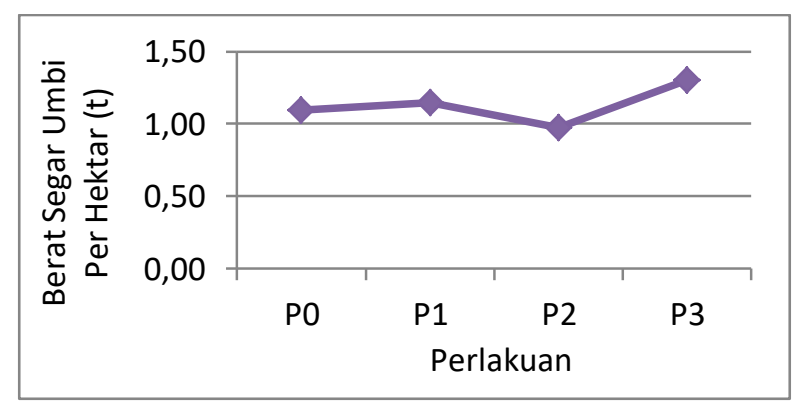

Gambar 9. Rata-rata berat segar umbi per hektar

\section{Pembahasan}

Hasil penelitian menunjukkan bahwa secara umum perlakuan $T$. asperellum dan kompos berpengaruh tidak nyata terhadap beberapa parameter pertumbuhan maupun komponen hasil tanaman bawang merah varietas lembah palu. Pengaruh yang nyata penggunaan $T$. asperellum dan kompos hanya didapatkan pada pengamatan tinggi tanaman 15 dan 25 HST. Hasil penelitian ini tidak sejalan dengan hasil-hasil penelitian
e-ISSN : 2621-7236

p-ISSN : 1858-134X

sebelumnya yang menunjukkan bahwa penggunaan Trichoderma memberikan pengaruh yang nyata terhadap parameter pertumbuhan dan hasil tanaman tomat (Simarmata, 1994). Pengaruh yang tidak nyata penggunaan $T$. asperellum dan kompos pada penelitian ini kemungkinan disebabkan adanya variabilitas respon tanaman terhadap kolonisasi Trichoderma (Poulton et al., 2011). Tiap kombinasi cendawan Trichoderma terhadap tanaman mempunyai fungsi dan tanggap yang berbeda pada tanaman dalam hal serapan hara, pertumbuhan dan reproduksi tanaman (Smith et al., 2003).

Berdasarkan Tabel 1. pemberian kompos cenderung memberikan pengaruh lebih baik terhadap tinggi tanaman pada umur 15 dan 25 HST, meskipun berbeda tidak nyata dengan perlakuan yang lain kecuali kontrol dan berpengaruh tidak nyata pada umur $35 \mathrm{HST}$, hal ini diduga bahwa aplikasi $T$. asperellum pada penelitian ini belum optimal. Hal ini sejalan dengan penelitian Umiyati (2017), pemberian Trichoderma yang belum optimal berpengaruh tidak nyata terhadap parameter pertumbuhan dan hasil tanaman bawang merah, namun berpengaruh pada tinggi tanaman.

Respon pertumbuhan tanaman bawang merah varietas lembah palu dengan perlakuan kompos yang terdiri dari campuran alang-alang, daun gamal dan Chromolaena odorata yang dicobakan sangat rendah bila dibandingkan dengan potensi genetiknya (Lampiran 20). Hal ini dapat dilihat dari pengamatan jumlah daun dan tinggi tanaman yang hanya mencapai rata-rata masing-masing 8.8 helai/rumpun dan $17.07 \mathrm{~cm}$. berdasarkan deskripsi bawang merah varietas Lembah Palu bahwa jumlah daun dan tinggi tanaman dapat mencapai 50 - 55 helai/rumpun dan $36-37 \mathrm{~cm}$.

Pertumbuhan tanaman yang rendah pada umumnya akan berimplikasi pada rendahnya produksi. Asumsi tersebut sesuai dengan hasil penelitian ini bahwa komponen hasil tanaman bawang merah varietas lembah palu masih jauh dibawah potensi genetiknya. Hasil tertinggi jumlah umbi per rumpun, berat umbi per rumpun dan hasil per hektar yang diperoleh masingmasing 6.52 buah/rumpun, $7.09 \mathrm{~g} /$ rumpun dan 2.04 ton/ha. Sementara berdasarkan deskripsi bawang merah varietas Lembah Palu bahwa jumlah umbi per rumpun, berat umbi per rumpun dan hasil per hektar masing-masing dapat mencapai $9-12$ b uah/rumpun, 35,1 - 68,4 g/rumpun dan 9,7 ton/ha. 
Faktor biotik dan abiotik yang diduga menyebabkan rendahnya produktivitas bawang merah varietas lembah palu pada penelitian ini adalah kondisi media tumbuh lahan percobaan yang kurang mendukung untuk pertumbuhan dan perkembangan tanaman. Berdasarkan Lampiran 17. kandungan unsur hara setelah panen dengan penambahan campuran alang-alang, daun gamal dan $C$. odorata rendah, seperti C-Organik yang hanya memiliki kadar $1,45 \%$. C-Organik tanah menggambarkan keadaan bahan organik dalam tanah, sementara tanah yang subur memiliki kandungan C-Organik tidak kurang dari 5\% (Idris, 2018). C-Organik tanah dapat mempengaruhi sifat tanah menjadi lebih baik secara fisik, kimia dan biologi. Karbon merupakan sumber makanan mikroorganisme tanah, sehingga keberadaan C-Organik dalam tanah akan memacu kegiatan mikroorganisme meningkatkan proses dekomposisi tanah dan juga reaksi-reaksi yang memerlukan bantuan mikroorganisme, misalnya pelarut $\mathrm{P}$ dan fiksasi N (Utami \& Handayani, 2003).

Berdasarkan Gambar 3, 4, 5 dan 6 perlakuan T. asperellum lebih rendah dibandingkan perlakuan yang lain. Hal ini diduga karena rendahnya konsentrasi hara yang terdapat pada tanah. Pada penelitian ini $T$. asperellum diaplikasikan dengan cara disemprotkan ke tanah. Simartama dkk., (2004) menyatakan bahwa keefektifan cendawan Trichoderma berkaitan dengan faktor lingkungan tanah abiotik (konsentrasi hara, $\mathrm{pH}$, kadar air, temperatur, pengolahan tanah dan penggunaan pupuk/pestisida) dan faktor biotik (interaksi mikroba, spesies cendawan, tanaman inang dan kompetisi antara cendawan Trichoderma).

Selain itu kandungan N-Total yang sangat rendah hanya memiliki kadar $0,08 \%$. Unsur hara yang dimiliki pupuk kompos hanya sedikit. Dengan begitu, dalam memenuhi kebutuhan hara pada tanaman, dibutuhkan jumlah pupuk yang relatif banyak dibandingkan penggunaan pupuk kimia. Salah satu kriteria mutu kompos yang baik adalah nisbah $\mathrm{C} / \mathrm{N}$. Nisbah $\mathrm{C} / \mathrm{N}$ yang tinggi (>30:1) pada kompos belum matang menyebabkan dekomposisi yang lambat dan menghambat pertumbuhan tanaman karena kekurangan nitrogen tersedia (Setyorini, $d k k$. 2003).

Rata-rata berat segar umbi cenderung lebih rendah pada aplikasi $T$. asperellum dan kompos (Gambar 7, 8 dan 9). Hal ini diduga karena kurang optimalnya proses penyebaran $T$.
p-ISSN : 1858-134X

asperellum saat aplikasi sehingga proses dekomposisi cendawan $T$. asperellum terhadap kompos kurang merata. Menurut Silvianingsih $d k k$ (2005) pertumbuhan cendawan Trichoderma paling baik pada daun yang kelembapan udaranya $100 \%$ dengan $\mathrm{pH}$ daun 3. Penelitian yang dilakukan Mulianingsih (1995) menghasilkan, bahwa serasah daun A. mangium yang diinokulasi Trichoderma terjadi dekomposisi yang efektif disebabkan oleh ciri morfologis daun dan kandungan selulosa serta ligninnya. Lebih lanjut dijelaskan, bahwa daun yang lebih banyak mengandung selulosa lebih mudah dirombak menjadi substrat yang sederhana dibanding lignin. Menurut Alexander (1977), bahwa Trichoderma merupakan salah satu cendawan lignoselulotik yang sangat kuat dalam mendegradasi selulosa dan lignin, karena menghasilkan enzim selulase yang dapat merombak kristal selulosa secara efisien. Jadi membuat media yang sesuai kondisinya sangatlah penting untuk memaksimalkan aktivitas organisme.

Keadaan iklim juga sangat mempengaruhi pertumbuhan dan perkembangan tanaman. Pada saat penanaman sampai panen kondisi iklim tidak menentu (lampiran 18), hal ini menyebabkan tanaman mudah terserang oleh penyakit. Menurut pendapat Suhardi, $d k k$ (1994), jenis yang dikatakan tahan atau toleran dalam kondisi yang tidak menentu dan berlangsung secara terus menerus, lama kelamaan toleransinya dapat menurun juga, akibatnya mudah terserang penyakit, sehingga kadangkala dalam kondisi ekstrim tersebut di alam daya saingnya sangat cepat sekali menurun.

Ruhiyat (1999) menyatakan, elemen-elemen iklim yang sesuai untuk perkembangan populasi dan kegiatan mikroorganisme terutama suhu dan kelembapan udara yang sangat optimal (Lampiran 19). Beberapa dekomposer seperti jamur dalam kondisi lingkungan yang optimum dapat membiak sangat cepat terutama pada keadaan yang lembap dan banyak mengandung bahan organik, hanya kekeringanlah yang menjadi faktor penghambat pertumbuhannya (Suriawiria, 1993; Parinkina dan Piin, 1989).

Nurfarm (2019) dalam Aminah dkk., 2019 mengemukakan cara sederhana pengendalian penyakit yaitu menanam bawang merah di lahan yang mempunyai drainase baik dan sebaiknya dilakukan penyiraman setelah turun hujan. Cara ini dapat mengurangi serangan penyakit karena meluruhkan percikan spora yang ikut bersama air 
hujan dan tanah. Hal ini juga diduga merupakan salah satu penyebab adanya serangan penyakit pada penelitian ini, yaitu tidak dilakukannya penyiraman setelah turunnya hujan.

Menurut Bugisinesia $d k k$ (2008) jika iklim tidak menentu seperti curah hujan tinggi maka Trichoderma tidak mampu bekerja dengan baik. Namun penggunaan Trichoderma dapat bekerja dengan baik jika kondisi lingkungan memungkinkan jamur ini berkembang. Selain itu Trichoderma dapat memperbaiki ketersediaan N, $\mathrm{P}$ dan $\mathrm{K}$ dalam bahan organik dan penggunaan komposnya meningkatkan kadan $\mathrm{N}, \mathrm{P}$ dan $\mathrm{K}$ sehingga tersedia dalam tanah.

Trichoderma spp. mempunyai mekanisme pengendalian bersifat spesifik target mampu mengkoloni bagian rizosfer dan rizoplan dengan cepat serta melindungi akar dari serangan cendawan patogen, dapat mempercepat pertumbuhan tanaman dan meningkatkan hasil produksi tanaman. Ada banyak cara mikroorganisme antagonis bekerja antara lain adalah kompetisi makanan dan ruang, sebagai mikroparasit atau lisisnya patogen, menghasilkan antibiotik (Nusret dan Steven, 2004).

Cara aplikasi dan dosis Trichoderma juga mempengaruhi penyebaran mikroba. Menurut Santoso $d k k$ (2007), perlakuan siram mampu memperlambat pemunculan gejala awal, yang diduga karena mikroba antagonis yang diinokulasikan mampu menyebar, terutama karena adanya aliran siraman. Hal ini sesuai dengan pendapat Davies \& Whitbread (1989), bahwa mikroba antagonis dapat bergerak menyebar secara pasif melalui air dengan adanya penyiraman selama pemeliharaan.

Pernyataan tersebut tidak sejalan dengan hasil penelitian ini, terlihat pada Gambar 1. sampai Gambar 9. dimana komponen parameter pertumbuhan dan hasil lebih tinggi pada aplikasi kompos dibanding perlakuan T. asperellum dan kombinasi dengan kompos. Hal ini diduga karena $T$. asperellum yang digunakan berasal dari filosfer kurang mampu beradaptasi dengan lingkungan di tanah dibanding Trichoderma asal rizosfer. T. asperellum yang berasal dari filosfer dan rizosfer memiliki kemampuan dalam menekan pertumbuhan patogen dengan persentase masing $39.26 \%$ dan $49,11 \%$ (Ratnawati, 2019). Kemampuan masing-masing Trichoderma spp. dalam mengendalikan cendawan patogen berbeda-beda, hal ini disebabkan morfologi dan fisiologinya berbedabeda (Kuswinanti, 2012).

\section{Kesimpulan}

1. Perlakuan berbagai kombinasi T. asperellum dan kompos berpengaruh nyata terhadap tinggi tanaman umur 15 dan 25 HST, tetapi berpengaruh tidak nyata terhadap jumlah daun, berat segar daun, berat segar akar, berat kering daun, berat kering akar, jumlah umbi per rumpun, berat segar umbi per rumpun, berat segar umbi per petak dan berat segar umbi per hektar.

2. Perlakuan kompos memberikan pengaruh lebih baik terhadap tinggi tanaman umur 15 HST (rata-rata $15,09 \mathrm{~cm}$ ) dan 25 HST (ratarata $19,86 \mathrm{~cm}$.

\section{Daftar Pustaka}

Alexander, M. 1977. Introduction to Soil Microbiology. John Wiley and Sons Inc., New York

Aminah. S.N.N., Ratnawati., Syamsiah. 2019. Penyakit Benih dan Teknik Pengendaliannya. Leutikaprio. Yogyakarta

Bugisinesia, T., U. Nurwaidah dan A. Gafar. 2008. Pengaruh Teknik Aplikasi Cendawan Antagonis Trichoderma spp Menekan Penyakit Layu Fusarium (Fusarium oxysporum $f . \quad s p)$ Tanaman Kentang (Solanum tuberosum L.). Prosiding Seminar Ilmiah dan Pertemuan Tahunan PEI dan PFI XX Komisariat Daerah Sulawesi Selatan

Idris. 2018. Pengaruh Berbagai Jenis Pupuk dan Dosis Pupuk Kandang Terhadap Pertumbuhan dan Hasil Tanaman Bawang Merah Lembah Palu. Tesis. Universitas Tadulako. Palu

Kuswinanti. T. 2012. Menguak Tabir Kehidupan Mikroorganisme. Kerjasama IPB Press dan Hasanuddin Unyversity Press

Liswarni, Y., Rifai, F., \& Fitriani. 2007. Efektivitas Beberapa Spesies Trichoderma untuk Mengendalikan Penyakit Layu pada Tomat, yang Disebabkan oleh Fusarium oxysporum. J. Litbang Pertanian

Mulianingsih, T. 1995. Studi Pengaruh Inokulasi Trichoderma viride dan Trichoderma resei pada Laju Dekomposisi Serasah Acacia mangium Willd. Skripsi Sarjana Fakultas Kehutanan. Institut Pertanian Bogor

Nurbailis dan Martinus, 2011. Pemanfaatan Bahan Organik Sebagai Pembawa Peningkatan Kepadatan Populasi 
Jurnal Agratech 10 (1) 27-34, Juni 2020

Trichoderma viride Pada Rizosfir Pisang dan Pengaruhnya Terhadap Penyakit Layu Fusarium. Jurnal HPT Tropika

Nusret, O., Steven. E. Newman, 2004. Biological Control with Trichoderma spp. with Emphasis on T. harzianum. Pakistan Journal of Biological Science

Poulton J.L., R.T Koide dan A.G. Stephenson. 2011. Effects of Trichoderma Infection and Soil Phosphorus Availability on In-vitro and In-vivo Pollen Performance in Lycopersicon escculentum (Solanaceae). American J. Botany

Ratnawati. 2019. Keragaman Organisme dan Peranan Cendawan Antagonis untuk Pengendalian Penyakit Bercak Ungu (Alternaria porri) pada Tanaman Bawang Merah Lokal Palu di Kabupaten Sigi Sulawesi Tengah. Disertasi. Program Studi Ilmu Pertanian. Universitas Hasanuddin. Makassar. (Belum dipublikasikan)

Santoso, E., Turjaman, M., dan Irianto, R. 2007. Aplikasi Mikoriza untuk Meningkatkan Kegiatan Rehabilitasi Hutan dan Lahan Terdegradasi. Prosiding. Ekspose HasilHasil Penelitian. Padang

Setyorini, D., Soeparto., Sulamen. 2003. Kadar Logam Berat dalam Pupuk. Prosiding Seminar Nasional Peningkatan Kualitas Lingkungan dan Produk Pertanian. Badan Litbang Pertanian

Silvianingsih Y.A., Mardji D., dan Simarangkir B.D.A.S. 2005. Pengaruh Kelembapan Udara dan pH Daun terhadap Proses Dekomposisi Tiga Jenis Daun oleh Trichoderma viride Pers. dan Em4. Universitas Mulawarman. E-Jurnal
e-ISSN : 2621-7236

p-ISSN : 1858-134X

Simarmata. T.1994. Teknologi Pupuk Organik. Dirgen Tanaman Pangan. Departemen Pertanian.

Simartama. T., R. Hindersah., M. Setiawati., B. Fitriani., P. Suriatmana., Y. Sumarni dan D. Hudaya Arif. 2004. Strategi Pemanfaatan Pupuk Hayati CMA dalam Revitalisasi Ekosistem Lahan Marginal dan Tercemar. Workshop Inokulum Produksi CMA. Lembang

Smith S.E., F.A. Smith dan I. Jacobsen. 2003. Trichoderma Fungi can Dominate Phosphate Supply to Plants Irrespective to Growth Responses. Plant Physiology

Suhardi, T, Koestoni \& AT, Soetiarso. 1994. Pengujian Teknologi Pengendalian hama Terpadu pada Tanaman Bawang Merah Berdasarkan Ambang Kendali dan Modifikasi Tipe Nozzle Alat Semprot. Bul. Penel. Hort

Sutanto, R. 2002. Penerapan Pertanian Organik (Pemasyarakatan dan Pengembangannya). Kanisius Yogyakarta

Sutaya, R.,G. Grubben, dan H. Sutarno. 1995. Pedoman Bertanam Sayuran Dataran Rendah. UGM Press. Yogyakarta

Umiyati Deden.U. 2017. Pengaruh Inokulasi Trichoderma sp. Dan Varietas Bawang Merah terhadap Penyakit Moler dan Hasil Tanaman Bawang Merah (Allium ascalonicum L). E-Jurnal. Padjajaran University

Utami, S.N. dan Handayani, S. 2003. Sifat Kimia Entisol pada Sistem Pertanian Organik. Ilmu Pertanian 